\title{
Philosophical Considerations: Economical, Epistemological, Cultural and Social Issues
}

\author{
VYTIS VALATKA \\ Department of Philosophy and Cultural Studies, Faculty of Creative Industries, Vilnius Gediminas Technical University, 26 Pylimo/ \\ 1 Trakų Street, 00132 Vilnius, Lithuania \\ Email:vytis.valatka@vgtu.lt
}

\begin{abstract}
This article analyses and interprets multiple links and interconnections among philosophy, economics, management as well as cognitive, cultural, social, political and educational sciences. Those links and interconnections are investigated in the frames of four methodological paradigms. The first paradigm connects counting, managing and reflecting. The second paradigm is a certain combination of discovering, thinking and solving. The third paradigm binds acting as overcoming, choosing and alternating. Finally, the fourth one relates acts of criticism, creation and construction. This issue is divided into four sections corresponding to the above-mentioned paradigms. This article, in turn, gives concise reviews and interpretations of articles presented in each of the aforementioned sections. Those reviews and interpretations link and bring together different topics of diverse disciplines, such as econometric counting, participation of youth in family business, transformation of classical concept of causality, solving logical paradoxes, trying to overcome various forms of nihilism, seeking alternatives to consumerism, searching for social equality, safety, security and inclusion.
\end{abstract}

Keywords: philosophy, economics, cognitive sciences, social sciences, cultural studies, links and interconnections

The universal perspective of philosophical reflection links and brings together various economical, managerial, epistemological, logical, ethical, cultural, societal, legal, political and similar problems. It is the main and peculiar characteristic of philosophical consideration that any aspect of any phenomenon or process can get into the focus of this consideration becoming its object. That does not mean that philosophy hopes to give the objective positive or negative evaluation of a certain phenomenon, process or action. If we required this from philosophy, we would require too much. On the contrary, philosophy is the space of eternal questioning including exploring, examining, approaching, researching, analysing, interpreting, explaining, etc.

However, philosophy lives and acts within multiple links and connections with other disciplines. For example, economics and management are closely related to ethics and political philosophy as the branches of practical philosophy. The latter considers, among the others, the issues of morality, social justice as well as welfare of individuals and certain social groups and the ways to reach it. All these issues are inseparable from correct logical thinking as the means to achieve the set cultural, social and political goals including the overcoming of contemporary nihilism and consumerism as well as ensuring social equality, safety, security and inclusion. 
So, there are multiple links and interconnections among philosophy, economics, management as well as cultural and social studies. Those links and interconnections have been analysed recently by Anderson (2000), Arrow (1994), Baudrillard (2001), Hodgson (2001), Howley (2003), Coca, Caballero, Carrera, Paramá (2018), Musarat, Sohail, Sarkar, Hafeez (2017), Pruskus (2014, 2017), Yi (2018), etc. In this issue, the above-mentioned links and interconnections are interpreted in four sections based on four methodological paradigmscombination of discovering, thinking and solving; the third one binds acting as overcoming, choosing and alternating, while the last one relates acts of criticism, creation and construction.

The first paradigm launches philosophical considerations on economical as well as managerial issues. In the article Philosophy of Economics: The Constructivist and Scientific Realist Interpretation of Macroeconomics, the authors deliver a comparative analysis of two philosophical ways of viewing macroeconomical reality. This analysis mainly rests on the works of McCloskey (1998), Blaug (1992), Giedymin (1986), Sady (2001), etc. The authors of the article notice that philosophy of economics mostly focuses on analysing the relation between model and reality. Yet, it does not pay enough attention to the process of model construction. This article tries to fill this gap in the contemporary philosophy of economics. First of all, the authors affirm that the prevailing conception of philosophy of economics is a certain mix of logical positivism and scientific realism. This mainstream position regards the certitude of empirical observations as higher than that of theoretical hypotheses. Hence, every rational econometric modelling should base itself on strict empirical observations. For this occasion, only, the results of econometric modelling are considered as descriptions of reality. Yet, the authors of the article deconstruct this predominant position. They stick to the so-called Fleckian constructivist philosophy that emphasizes the conventionalist/constructivist aspect of empirical research. According to them, the results of empirical macroeconomic observation directly depend on methods employed by the observers. Hence, the alleged descriptions of macroeconomic reality are nothing but human constructions generated by quantitative methods.

One of the main objectives of philosophies of economics and management is to relate and translate theoretical principles, ideas and concepts into reality. The article Philosophy of Economics and Management: Youth Participation in Family Business and National Economy strives to apply considerations on philosophical premises of economics and management to empirical research identifying youth's attitudes towards their involvement in family business, based on descriptive statistics methods. While doing that, the authors of the article pay most attention to the works of Horkheimer (1947, 1974), Stewart (1995), Greer (1999), Zellweger (2017), Murphy et al. (2015), etc. Family is interpreted here in terms of ethics as well as political and economic philosophy as a favourable space to form economic attitudes of young people that are not reduced to a merely individualistic rationality of homo oeconomicus. Hence, the article challenges the fundamental economic notion of rational pursuit of individual profit and transfers it in a broader context of rationalities based on familial, communitarian and universalistic values. As for the above-mentioned empirical research, it basically confirms the hypothesis that young person's readiness to work in the family business as well as take it over in the future depends on whether he/she is already involved in it during studies.

The second paradigm involves considerations on epistemological and logical issues. Among the main objects of epistemological research, there are the fundamental principles, laws and concepts of human cognition and discovery. One of the principles of that sort leading to the discovery of new facts is a concept of causality. The latter is being analysed and interpreted in epistemology from its very beginning. The article The Transformation of Mod- 
ern Causality in Heidegger's Thought concentrates on the analysis of the Heideggerian notion of causality in the context of philosophy and science of Modernity. Such an analysis is principally based on the works of Aristotle (1837), Hobbes (1839), Heidegger (1969, 1979), Gonzalez (2006), etc. According to the author, the modern notion of causality is a combination of the concepts of extensive space, sufficient ground, object cognizable through mathematical description and the linear time. However, within Heidegger's conception of Being as unconcealement, all the above-mentioned notions were deconstructed and transformed. These transformations resulted in the non-algebraic notion of space, the temporalized principle of ground, the concept of constant presence as well as the notion of ecstatic time. Those transformative parameters shape the so-called Heideggerian conception of causality that opened and still opens new horizons of cognition and discovery.

Logic is usually defined as the theory of correct reasoning and valid argumentation. One of the essential tasks of such a correct reasoning is to solve various semiotic, semantic, pragmatic and similar paradoxes. The article Wittgenstein's Tractatus Logico-Philosophicus and a Hierarchical Approach to Solving Logical Paradoxes works on this task. Based on the works of Russel (1908), Tarski (1935), Wittgenstein (1921), Sainsbury (2009) and the others, the author concentrates on the hierarchical approach to solving logical paradoxes. Russell's theory of types and Tarski's semantic conception are interpreted as the representative examples of such a hierarchical approach. The author also accepts criticism of the above-mentioned theories presented in the contemporary discourse of logic, epistemology and the philosophy of mathematics. Nevertheless, the Wittgensteinian version of a hierarchical approach found in Tractatus Logico-Philosophicus is regarded as the most suitable as well as the most resistant one to the above-mentioned criticism, as it considers hierarchy not as some artificial methodological invasion into language but as its intrinsic feature. Therefore, if, according to the author, we want to demonstrate that a hierarchical approach is a valid way to solve the problem of paradoxes, we should follow the steps of Wittgenstein.

The third paradigm generates considerations on cultural and ethical issues. Within the frames of contemporary society and civilization, one of the main ethical and cultural problems is nihilism, having acquired multiple forms as well as global proportions. Such a situation encourages ethical and cultural discourses to propose the ways to solve the aforementioned problem. The article The Perspective of Overcoming Nihilism in Heidegger's Dialogue with Jünger emphasizes the proposal of one of the most famous philosophers of the 20th century Martin Heidegger (1977), put forward in response to the position of his colleague and friend Ernst Junger (1960). This proposal is interpreted in the context of the works of Mickūnas and Jonkus (2014), Kačerauskas and Věželis (2016), etc. The author underlines that, contrary to Junger, Heidegger saw nihilism as lying at the core of the history of Western civilization and philosophical thinking where the main place is given to Nothing as an inseparable shadow of Being. Therefore, nihilism cannot be overcome by traditional means of dialectical thinking and its language. On the contrary, this purpose requires the new language as the place of revelation and speaking of the Being itself.

Within the frames of contemporary consumer civilization, the development of modern sciences and technologies opens multiple possibilities and alternative choices to its citizens. Yet, the permanent consumption, a desire to have more and faster, wears and exhausts a contemporary man imprisoning him in the never-ending wheel of hurry and not allowing himself to contend with simple things of everyday life. According to Bauman (2007), the consumer commodity market has already become an absolute sovereign deciding human destinies. In this 
critical situation there is an evident need for radical alternation, i.e. alternatives to consumerist ethics and way of life. The article Alternatives to the Culture of Consumerism, or the Charm of Skeptical Solitude searches for the alternatives of that sort. Based on works of Montaigne (1992), Rousseau (1992), Marquard (1995), Cox (2016), etc., the author of the article proposes the position of skeptical solitude. The latter is defined as a life beyond attitudes and habits of never-ending consummation and any dogmas in general, as well as conventions and public opinions. More to say, it is the life within inner peace and lack of care opening space for independent observing, thinking and authentic communication.

The fourth paradigm opens space for considerations on social, political and educational issues. The 20th century was the time when human rights of various kinds were announced, officially promulgated by various international juridical documents as well as started to be practically implemented. The aforementioned processes gave birth to the theoretical discourse on human rights that resulted in philosophy of human rights. Within the frames of this discourse, it is very important not to leave a historical perspective out of consideration. The latter allows us to identify the ideological, political and historical background of the human rights as well as ensures deeper, wider and sounder understanding of this phenomenon. The article Diderot's Criticism of Colonialism: Plea for Equality and Reciprocity among Peoples goes exactly this way. Its author searches for the theoretical preconditions and beginnings of human rights in the works of the famous French encyclopaedist and philosopher Diderot (1994-1997). The main emphasis is laid on Diderot's criticism on colonialism and slavery, his advocacy of cosmopolitism and principle of equality among human beings and nations, as well as arguments for the position that moral codes of the so-called savage nations are by no means less elevated than those of the European civilization.

Contemporary society faces the set of crucial problems threatening to its welfare, safety and security. The above-mentioned set includes terrorism, aggressive forms of religious fundamentalism, xenophobia, homophobia, mobbing, social exclusion, poverty, unemployment, hunger, homelessness, etc. Such a situation encourages philosophical, cultural and social discourses to propose the ways that could contribute to solve the aforementioned problems. The article The Construction of the Homeless as a Discursive-political Struggle: A Discursive-theoretical Re-reading of the Homeless Subject Position analyses the phenomenon of poverty. Based on works of Levinson (2004), McNamara (2008), Laclau and Mouffe (1985), Howley (2005), etc. and using methods of social and political philosophy, the authors of the article concentrate on the homeless identity, or the homeless subject position. Analysing various sides and aspects of this position, they also disclose its contested nature and how it becomes an object of political struggle. This struggle rages on mainly between mainstream mass media and the so-called street press, both using different tools to take the dominant position in constructing and interpreting homeless identity.

Another important problem of contemporary society is a lack of inclusion of the disabled people into secondary and higher education. This problem involves discrimination against members of a certain group of society and the inability to ensure equal opportunities. In the article Equal Opportunities and Dignity as Values in the Perspective of I. Kant's Deontological Ethics: The Case of Inclusive Education people with disabilities are presented as equal members of society with equal rights to both upper secondary and tertiary education, as are those who have no physical or mental disability. In order to promote the inclusion of disabled people, its importance is demonstrated by the axiological position of the German philosopher Immanuel Kant (2013), based on a categorical imperative as a universal ethical maxim. 


\section{CONCLUSIONS}

Philosophy is the universal discipline capable of reflecting various sides, angles and aspects of diverse phenomena, processes as well as actions. That is why philosophy lives and acts within multiple links and connections with the other disciplines, such as economics, management, cognitive and educational sciences; cultural, social, political studies and so on. These links and interconnections could be analysed and interpreted within frames of various methodological paradigms involving methods as well as cognitive strategies of the aforementioned disciplines. Those paradigms, in turn, launch philosophical considerations that link and bring together different topics of diverse disciplines, such as econometric counting, participation of youth in family business, transformation of the classical concept of causality, solving logical paradoxes, trying to overcome various forms of nihilism, seeking alternatives to consumerism, searching for social equality, safety, security and inclusion.

\section{References}

1. Anderson, E. 2000. "Beyond Homo Economicus: New Developments in Theories of Social Norms", Philosophy \& Public Affairs 29(2): 170-200.

2. Arrow, K. J. 1994. "Methodological Individualism and Social Knowledge", The American Economic Review 84(2): 1-9.

3. Baudrillard, J. 2001. "Consumer Society", in Selected Writings, ed. M. Poster. Stanford: Stanford University Press, 32-59.

4. Bauman, Z. 2007. Consuming Life. Cambridge: Polity Press.

5. Blaug, M. 1992. The Methodology of Economics: Or, How Economists Explain. Cambridge University Press.

6. Coca, J. R.; Caballero Caballero, I.; Carrera, F. J. F.; Paramá, A. 2018. “Technoscience, Hermeneutic and Society Oriented to the Person", Filosofija. Sociologija 29(3): 185-194.

7. Cox, H. 2016. The Market as God. Harvard University Press.

8. Diderot, D. 1994-1997. CEurres. Ed. L. Versini. Paris: Robert Laffont.

9. Giedymin, J. 1986. "Polish Philosophy in the Inter-war Period and Ludwik Fleck's Theory of Thought-styles and Thought-collectives", in Cognition and Fact. Springer Netherlands, 179-215.

10. Gonzalez, F. J. 2006. "Whose Metaphysics of Presence? Heidegger's Interpretation of Energeia and Dunamis in Aristotle", Southern Journal of Philosophy 44(4): 533-568.

11. Greer, M. R. 1999. "Individuality and the Economic Order in Hegel's Philosophy of Right", Journal of the History of Economic Thought 6(4): 552-580.

12. Heidegger, M. 1969. "The Principle of Identity", in Martin Heidegger. Identity and Difference. Transl. by J. Stambaugh. New York, Evanston, London: Harper \& Row Publishers.

13. Heidegger, M. 1977. Zur Seinsfrage. Frankfurt am Main: Vittorio Klostermann.

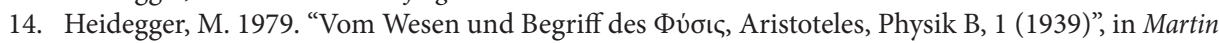
Heidegger. Gesamtausgabe. I. Abteilung: Veröffentlichte Schriften 1917-1970. Bd. 9: Wegmarken. Frankfurt am Main: Vittorio Klostermann.

15. Hobbes, Th. 1839. "Elementorum philosophiae sectio prima De corpore", in Thomae Hobbes Malmesburiensis opera philosophica, quae latine scripsit, omnia in unum corpus nunc primum collecta studio et labore Gulielmi Molesworth. Vol. I. Londini: apud Joannem Bohn.

16. Hodgson, B. 2001. Economics as Moral Science. Heidelberg and New York: Springer.

17. Horkheimer, M. 1947. Eclipse of Reason. Oxford University Press.

18. Horkheimer, M. 1974. Critique of Instrumental Reason. Continuum.

19. Howley, K. 2003. "A Poverty of Voices: Street Papers as Communicative Democracy", Journalism 4(3): 273-292.

20. Jünger, E. 1960. Über die Linie. Frankfurt am Main: Vittorio Klostermann.

21. Kačerauskas, T.; Věželis, T. 2016. Šiapusybès regionai: 50 Heideggerio filosofijos klausimų. Vilnius: Technika.

22. Kant, I. 2013. The Metaphysics of Morals. Cambridge: Cambridge University Press. 
23. Laclau, E.; Mouffe, C. 1985. Hegemony and Socialist Strategy: Towards a Radical Democratic Politics. London: Verso.

24. Levinson, D. 2004. Encyclopedia of Homelessness. 2 volumes. Thousand Oaks: Sage.

25. Marquard, O. 1995. Skepsis und Zustimmung. Stuttgart: Phillip Reclam Jr.

26. Mickūnas, A.; Jonkus, D. 2014. Fenomenologiné filosofija ir jos šešèlis. Vilnius: Baltos lankos.

27. McCloskey, D. 1998. The Rhetoric of Economics. London: University of Wisconsin Press.

28. McNamara, R. 2008. Homelessness in America. 3 volumes. Santa Barbara: ABC-CLIO.

29. Montaigne, M. de. 1992. The Complete Essays of Montaigne. Stanford: Stanford University Press.

30. Murphy, L.; Lambrechts, F. 2015. "Investigating the Actual Career Decisions of the Next Generation: The Impact of Family Business Involvement", Journal of Family Business Strategy 6(1): 33-44.

31. Musarat, Y.; Sohail, Sh.; Sarkar, M.; Hafeez, R. 2017. "Creative Methods in Transforming Education, Using Human Resources”, Creativity Studies 10(2): 145-158.

32. Pruskus, V. 2014. „Rinkos etinès ribos pilietinès visuomenès tapsmo, profesijos autonomiškumo ir asmeninių santykių kontekste", Logos 79-80: 153-163, 173-177.

33. Pruskus, V. 2017. Ekonomika ir filosofija: squveikos ir trajektorijos. Vilnius: Technika.

34. Rousseau, J.-J. 1992. The Reveries of the Solitary Walker. Transl. by C. E. Butterworth. Indianapolis/ Cambridge: Hackett Publishing Company.

35. Russell, B. 1908. "Mathematical Logic as Based on the Theory of Types", American Journal of Mathematics 30(3): 222-262.

36. Sady, W. 2001. "Ludwik Fleck-Thought Collectives and Thought Styles", Poznan Studies in the Philosophy of the Sciences and the Humanities 74: 197-206.

37. Sainsbury, R. M. 2009. Paradoxes. 3rd edn. Cambridge: Cambridge University Press.

38. Stewart, H. 2008. "A Critique of Instrumental Reason in Economics", Economics and Philosophy 11(1): $57-83$.

39. Tarski, A. 1935. "Der Wahrheitsbegriff in den formalisierten Sprachen", Studia Philosophica 1: 261405.

40. Yi, H. 2018. "Constitutive and Depictive Creativities in Philosophy and Critical Thinking", Creativity Studies 11(1): 25-40.

41. Zellweger, T. 2017. Managing the Family Business: Theory and Practice. Cheltenham, UK: Edward Elgar Publishing.

42. Wittgenstein, L. 1921. "Logisch-philosophische Abhandlung", Annalen der Naturphilosophie 14: 185262.

43. Aristotelēs. 1837. "Fusikē Akroaseōs. Ex. Rec. I. Bekker", in Aristoteles Graece, Volumen Prius. Bernolini: Apud Georgium Reimerum. 
VYTIS VALATKA

\title{
Filosofiniai svarstymai: ekonominiai, epistemologiniai, kultūriniai ir socialiniai klausimai
}

\begin{abstract}
Santrauka
Straipsnyje analizuojami daugialypiai ryšiai ir sąsajos tarp filosofijos, ekonomikos, vadybos, taip pat kognityvinių, kultūrinių, socialinių, politinių ir edukologinių tyrimų. Šie ryšiai ir sąsajos tiriami keturiomis metodologinių paradigmų perspektyvomis. Pirmoji paradigma sujungia skaičiavimą, vadybą ir refleksiją. Antroji - tai tam tikras atradimo, mąstymo ir sprendimo derinys. Trečioji paradigma susieja ịveikos, pasirinkimo ir alternatyvos siekimo veiksmus. Galiausiai, paskutinè paradigma sujungia kritiką, kūrimą ir konstravimą. Šis žurnalo numeris yra padalytas ị keturis skyrius, atitinkančius nurodytas paradigmas. Taip pat pateikiamos glaustos kiekvieno skyriaus straipsnių apžvalgos ir interpretacijos. Pastarosios susieja ir suartina tokias skirtingų mokslų temas kaip ekonometriniai makroekonomikos skaičiavimai, jaunimo dalyvavimas šeimos versle, klasikinès priežastingumo sampratos transformacija, loginių paradoksų sprendimas, bandymas ịveikti ịvairias nihilizmo formas, alternatyvų vartotojiškumui paieška; socialinès lygybès, saugumo ir inkliuzijos siekimas.
\end{abstract}

Raktažodžiai: filosofija, ekonomika, kognityviniai mokslai, socialiniai mokslai, kultūros studijos, ryšiai ir sąsajos 